\title{
From Colonial Policy to National Treasure: \\ Tracing the Making of Audiovisual Heritage in the Philippines \\ Bernadette Rose Alba Patino
}

This study traces the history and construction of institutionalized cultural and audiovisual heritage in the Philippines and investigates how evolving views of heritage have shaped the country's audiovisual archiving and preservation movement in the last fifty years. It examines the impact of naturalized definitions of heritage, as globalized by the United Nations Educational, Scientific, and Cultural Organization (UNESCO), and the implementation of audiovisual archival institution building, cultural policies, and archival priorities in the Philippines under the heritage banner set out by the organization. Considering the formation of what heritage scholars call "authorized heritage discourse" (AHD), this paper argues that a heritage hierarchy emerged in the country's contemporary audiovisual archiving landscape, privileging an industrial view of cinema while marginalizing other forms of moving image practice. The study calls for an awareness of and resistance to institutionalized archives' claims to social, cultural, and political power in their heritage construction and discourse.

Keywords: audiovisual heritage, audiovisual archiving, authorized heritage discourse, Philippine cinema, UNESCO cultural policies

Throughout the long history of the audiovisual archiving and preservation movement in the Philippines, a myriad of institutions, organizations, and individuals has wielded the concept of heritage to powerful effect. The phrase "save our heritage" as cultural policy and rallying point has propelled laudable actions like rescuing abandoned films, establishing a national film archive, and founding a regional Southeast Asian association of audiovisual archives. However, heritage has also been used to justify questionable practices like the creation of an industry-dominated film canon whose access is systematically corporatized and privatized; the launch of exclusive heritage preservation campaigns that, in a cruel twist of fate, have resulted in the marginalization, deprioritization, and deterioration of diverse forms of moving images; and even the inauguration of a building dedicated to the enrichment of cultural heritage amidst news of a cover-up on the death of numerous laborers during its hasty construction. ${ }^{1}$ Those that employ the concept of heritage with such authoritative gusto rarely question it, simply assuming its naturalized, inherent value as a unifying force necessary for national cultural development-a convention that is maintained and 
uncritically accepted within audiovisual archival institutions to this day, and not without certain material consequences.

In the absence of a critical historical investigation of heritage in the field of audiovisual archiving in the Philippines, this paper seeks to trace the history and construction of institutionalized Filipino cultural and audiovisual heritage, particularly how naturalized notions of heritage shaped early initiatives to establish audiovisual archival institutions and what local and international factors led to contemporary definitions of audiovisual heritage to be rendered as a canon of primarily industry-made, featurelength narrative cinema, specifically in the past twenty-five years. Following scholar and moving image archivist Caroline Frick's (2011) methodology of analyzing heritage as a socially constructed phenomenon, particularly her analysis on the role that the International Federation of Film Archives (FIAF) and the United Nations Educational, Scientific, and Cultural Organization (UNESCO) played in globalizing audiovisual materials as heritage, this study examines how both organizations impacted the Philippines' audiovisual preservation and archiving movement as a result of their postwar policies that encouraged promoting cultural development, especially through a national cultural institution building, as essential to legitimizing the nation on the international stage.

Heritage scholar Laurajane Smith's (2006) notion of "authorized heritage discourse" (AHD), together with her examination of its origins and UNESCO's policies as a product of AHD's historical process and development, informs the paper's analysis of heritage as cultural policyduring the American colonial regime in the Philippines up to the dictatorship of Ferdinand Marcos. I argue that despite the varied definitions of audiovisual heritage and what constitutes the national as offered by pioneering audiovisual archivists, a hierarchy of audiovisual heritage emerged in the late 1980s following the closure of the Film Archives of the Philippines (FAP), the country's first national-level audiovisual archive, at the height of the Marcos dictatorship and what was also UNESCO's first foray into recommending and assisting in the establishment of such institutions in the global south. The exclusive hierarchy placed feature-length narrative cinema at the pinnacle and its restoration as the ultimate archival priority, reflecting an embrace of a primarily industrial view of both Philippine cinema and audiovisual heritage.

While UNESCO played a significant role in instilling the heritage-asnational ethos in the Philippines and around the globe, the paper explores the layered and complex factors leading to the enduring hierarchy of audiovisual heritage that privileges an industrial view of cinema: the Marcos' utilization of cinema as a highly politicized diplomacy tool; the failure and closure of 
martial law-era audiovisual archiving institutions; destabilized institution building in which centralized national-level audiovisual archives were historically structured within government agencies dedicated to film industry development; the subsequent deprioritization of audiovisual archiving and access vis-à-vis national film production and exhibition set as precedent; and the lack of laws strengthening the protection and preservation of and access to a diversified audiovisual heritage-all of which continue to impact the curatorial decisions and archival priorities by contemporary Filipino audiovisual archival institutions. A critical examination of the hierarchy and its development presented in this paper is necessary to understand the shortcomings of an exclusive audiovisual archival practice in order to move toward one that advocates and supports public and community-centric participation in the very creation of heritage, encompassing an awareness of and resistance to institutionalized archives' claims to social, cultural, and political power in national heritage construction and discourse.

\section{Filipino Audiovisual Heritage in the Contemporary Landscape}

In 2012, the digitally restored versions of two Filipino films premiered in separate sections of the 69th Venice International Film Festival. To celebrate the festival's 80th anniversary, the Retrospective section featured Manuel Conde's 1965 film Genghis Khan among a roster of other such rare films archived at the Venice Biennale's Historical Archives of Contemporary Arts (ASAC). In parallel, the Venice Classics, a section devoted to restored classics in world cinema, featured Ishmael Bernal's 1982 film Himala. The premieres of the first-ever digitally restored films in Philippine cinemaboth of which are considered masterpieces by two of the country's National Artists for Film-garnered the same amount of attention and prestige as Brilliante Mendoza's film Thy Womb, an official selection in competition for the coveted Golden Lion that year. Together, the trio of films put on display on the global stage Philippine achievements in the cinematic arts. The inclusion of two restored Filipino "classic" films added a new dimension to the regular fanfare of a Filipino film selected to compete in an A-list film festival by calling attention to the greatness of the Philippines' audiovisual heritage, a perception reintroduced into the public consciousness and added a patriotic flare and vital cultural capital to the films at hand. The restorations of Genghis Khan and Himala signaled a new era of audiovisual archiving in the country, in which digital film restoration of feature-length films dominates archiving activity and discourse, affecting not only public perception of audiovisual archiving and heritage but also professional norms in the field. 
Indeed, the grandiosity demanded by the concept of "heritage" was not lost on the two institutions that spearheaded the digital restorations, both of which currently hold the country's largest audiovisual repositories. The Film Development Council of the Philippines (FDCP), a government arts body focused on developing the film industry, and ABS-CBN Corporation, the giant international media conglomerate, justify digital restoration of feature-length narrative films as an intrinsic, manifest step in the survival of Filipino audiovisual heritage and Philippine cinema itself. Since 2012, FDCP has organized multimillion-peso digital film restorations of approximately one title per year for a total of six restored feature-length films to date ${ }^{2}$ while ABS-CBN leads with over 100 titles restored (Cruz, 2016), far outnumbering both analog and digital restorations carried out by various institutions in the past twenty years alone.

Many may consider the influx of digital restorations in recent years a cause for celebration, but to unequivocally do so is to fail to recognize that the institutional fixation on restoration of a largely limited scope-primarily of industry-made feature-length films -is a symptom of a larger crisis: a severely parochial vision of what audiovisual archiving entails in practice and what audiovisual heritage encompasses in scope. FDCP spends well over half of its annual audiovisual preservation budget exclusively on film restoration of narrative feature-length films despite the fact that such films comprise barely a quarter of its entire collections, ${ }^{3}$ thereby casting aside the vast majority of its varied holdings in a variety of formats on celluloid, magnetic tape, and digital: short films, experimental and alternative works, documentaries, student and amateur films, wartime and martial law propaganda, as well as other such "non-film" films made for social utilization in different fields like education, medicine, sciences, sociology, and history. Moreover, the lack of financial investment, consistent experienced and knowledgeable leadership, and sheer political will to establish a permanent archival facility to house FDCP's holdings-a crucial project that has languished for nearly a decade-continues to put all collections at risk. Such shortcomings render the vast majority of collections inaccessible to the public. Likewise, little has been done to address the idle progress in developing staff, infrastructure, and access points since the inception of FDCP's archiving program in 2011. Meanwhile, as the main player in the private sector, ABS-CBN exclusively acquires feature-length films based on the potential of its commercial profitability and has systematically normalized the privatization of archival access (Cruzado, 2012). It cannot be left to compensate for the failures of state or independent archival institutions, despite its state-of-the-art facilities. 
It is no exaggeration to say FDCP and ABS-CBN's partisan practices and priorities have dominated institutional audiovisual archiving in the Philippines for most of the last decade. Their priorities, zoomed in on featurelength film restoration, have had long lasting and arguably devastating effects on the overall state of audiovisual archiving in the country, especially considering that smaller government and private archives that once formed the core of the audiovisual preservation movement in the 1990s have already turned over many of their collections to either of the two institutions (Lim, 2013). ${ }^{4}$ The hegemony of industrial narrative cinema in contemporary audiovisual heritage discourse and archival practice puts into question whether or not the utmost purpose of audiovisual heritage is to nurture an authorized national identity and unity and passive black-box cinematic exhibition as the sole means for access and community engagement. FDCP and ABS-CBN accepted this archival model as an inherent, matter-of-fact truth, which begs for a historical investigation of how their naturalized notions of heritage and institutional priorities came to be and of what is at stake when archivists and archiving institutions take heritage for granted.

\section{The "Script" of Audiovisual Heritage and Archival Practice}

Scholar and moving image archivist Caroline Frick (2011) emphasized in Saving Cinema: The Politics of Preservation that "those involved in moving image preservation have not merely preserved movie history; they have, instead, actively produced cinematic heritage" (p. 5). She noted that "the preservation of so-called national or state heritage is not, and never has been, a neutral concept, although it is presented as such by politicians, the press, intellectuals, and archivists" (p. 19). Archival practices derive from institutions and archivists' decision-making in specific cultural, political, social, and economic circumstances. Likewise in the Philippine context, by no means does the supposed innate value of heritage lead to the institutionalization of narrative cinema's digital restoration as the principal focus of audiovisual archiving today, even though institutions describe it as an inherent and noble duty in the grand narrative of preservation.

Assessing archives and archivists' agency in choosing the roles and practices they adopt, Canadian archivists Terry Cook and Joan Schwartz (2002) developed the idea of "archival performativity," observing that

the practice of archives is the ritualized implementation of theory .... it is a script formed by the 'social magic' of now-unquestioned, 'naturalized' norms. These norms are themselves generalized from past performances (practices) that archivists have collectively anticipated, over generations, would confer on them appropriate legitimacy, 
authority, and approval ... for not to do so would undermine our professional identity, our sense of security, our comfort with our internalized scripts. Our scripts have thus become naturalized. (p. 173)

Rather than question or dare to rewrite the script repeated over generations, FDCP and ABS-CBN choose to play the roles set out for them, leading to real material consequences in what does and does not get recognized as audiovisual heritage, and subsequently, in public accessibility, knowledge production, public participation in creating heritage, and claims to and uses of social and political power.

Cook and Schwartz's repeated "script" was given a historical dimension in heritage scholar Laurajane Smith's (2006) notion of "authorized heritage discourse" (AHD). Tracing its roots to the development of nineteenthcentury Western nationalism and liberal modernity, she defined AHD in her seminal work, Uses of Heritage:

There is a hegemonic 'authorized heritage discourse', which is reliant on the power/knowledge claims of technical and aesthetic experts, and institutionalized in state cultural agencies and amenity societies. This discourse takes its cue from the grand narratives of nation and class on the one hand, and technical expertise and aesthetic judgment on the other. The 'authorized heritage discourse' privileges monumentality and grand scale, innate artifact/site significance tied to time depth, scientific/aesthetic expert judgment, social consensus and nation building. It is a selfreferential discourse. (p. 4)

Here, Smith (2006) laid out a number or characteristics of AHD: It institutionalizes interpretations of the past for the purpose of maintaining a hegemonic hierarchy of values according to what is valuable on the national scale; emphasizes the tangibility of heritage, whose management and conservation is limited to the realm of experts and professionals; and remains self-referential in that the very experts that manage heritage and measure its value also claim heritage to be innately valuable and profess so to the public. A close examination of FDCP and ABS-CBN's archival practice-which insists on their exclusive authority on archival processes and priorities, the narrative that high-end digital restoration and exhibition is the ultimate tool to preserve the medium, and the definition of featurelength narrative cinema as the premier expression of national identityreveals their adherence to AHD. How did AHD become the "script" in current institutionalized audiovisual archival practice? 
In the historical process of heritage making, Smith (2006) and Frick (2011) pointed to a specific international body that globalized the idea of national heritage beyond its European borders for the rest of the world to adopt: UNESCO. Across the globe, this organization played an integral role transforming the definition of moving image from a general artistic and historical document to the elevated, international status of national cultural heritage in its postwar conventions, charters, and recommendations (Frick, 2011). In the Philippines, UNESCO served as an optimistic consultant during the establishment of the first national-level audiovisual archive, leaving an indelible mark on the country's audiovisual archiving and preservation movement and overall notions of what constitutes heritage. Cook and Schwartz (2002) stressed that "once we acknowledge 'archival practice' as a form of 'performance' of archives, we will be better able to become 'performance conscious"' (p. 185). Only then can the archival institution understand its role and conceive of new models to participate in knowledge production, collective memory and remembering, and negotiating cultural, social, and political change in the present through new meanings of the past.

\section{Historicizing Cultural Heritage: Enlightenment, Empire, and UNESCO}

An early signatory of the UN Declaration in 1942, the Philippines, still under American rule as a Commonwealth, became one of the founding member states of the UN alongside 49 other nations when it signed its charter in 1945 following the end of WWII. Even with strengthened powers to impose and enforce sanctions, the UN took a dual approach, also making efforts to emphasize soft diplomacy through its specialized agency UNESCO, by cultivating knowledge and understanding between peoples toward a common humanity as a means of conflict prevention. The Philippines gained independence from the United States with the signing of the Treaty of General Relations on July 4, 1946, and joined UNESCO just four months later. In 1951 the Second Congress of the Philippines passed Republic Act (RA) No. 621, which established the Philippine National Commission for UNESCO, formalizing the country's international commitment to the organization.

Three decades of WWII reconstruction saw the proliferation of newly independent nations, causing a turning point in UNESCO's evolving theoretical framework on culture: "The unique cultural identities of these nations, a justification for their independence and international existence, became a central political issue. The concept of culture was expanded to encompass 'identity' itself'” (UNESCO, 2004b, p. 3). This marked a 
significant change from the immediate postwar years when UNESCO defined culture as historical and artistic production, though not specifically a representation of national identity. According to Frick (2011), by the 1970s heritage emerged in UNESCO's theoretical framework as a valuable universal term needed to "better serve the articulation and exploitation of these varied, but specifically state-driven identities," as UNESCO began insisting that "all countries, regardless of social, economic, or cultural status possessed a unique heritage" (p. 103). Heritage then in UNESCO's policies evolved: it was not an immaterial concept but was intrinsically physical in form, meriting management, conservation, and preservation for posterity. ${ }^{5}$

Smith (2006) traced the origins of material heritage and its authorized discourse championedbyUNESCOback toliberal modernity: Enlightenment rationality brought about the ideas of objective truth and the concept of civilizational progress, legitimizing the Europeans' colonial and imperialist expansion by placing themselves at the pinnacle of the human advancement in technology, thought, and culture, as social Darwinism generated links that naturalized hierarchies along identity and race. Her study showed how museums, monuments, archeological expositions, and collections of antiquities became the trophies with which modern Europe educated its citizens and expressed its national identity, leading to a flood of legislation and policies for protection as "national heritage" throughout Europe, later emulated by the United States. With the collapse of imperial and dynastic powers, nation states needed "new devices to ensure or express social cohesion and identity to structure social relations ... . [and] methods of ruling and establishing forms of loyalty" (Hobsbawm, 1983, p. 263). The Philippines, the first country to have a nationalist revolution in Asia with the Philippine Revolution of 1896, has a long and rich history of nationalism dating back to the 1700s in resistance to Spanish colonial rule. How the burgeoning and evolving Filipino nationalism interacted with prevailing ideas of European material heritage through the Spanish and American regimes offers insights in future constructions of audiovisual heritage.

The Spanish empire pioneered architectural conservation in order to protect material heritage in Europe, sponsoring such projects as early as the fifteenth century, later following French models in the nineteenth century to construct a material Spanish heritage after the Bourbons rule in Spain (Stubbs \& Makaš, 2011). A lasting legacy of Spain's vested interest in such architectural conservation is the multitude of Spanish structures, particularly churches and fortresses throughout the Philippine archipelago, since the Spaniards utilized architecture and demarcation of space to impose religious and colonial power as a means of control. In the Spanish caste system in the Philippines, notions of Spanish "heritage" as 
blood lineage was apparent in constructions of "Filipino" identity and racial hierarchy in society during the Spanish rule, though it was not until the final decades of the nineteenth century that the identification "Filipino" was "reappropriated by nationalists to refer to all those that suffered under the Spaniards and sought change through reform or revolution" (Rafael, 2000, p. 7). Filipino national symbols existed in smaller scale through emblems and flags, which were already common signifiers for sovereign states by the nineteenth century.

The Filipino national identity and notions of cultural heritage went through further transformations under the U.S. regime, though not without contradictions stemming from the Americans' tactical shift from military control to benevolent assimilation by the 1910s. Alongside impositions in the use of English as the language of instruction in schools, Americans pronouncedly imposed Western constructs of large-scale material heritage as a means to control the development of national identity in its new colony. Along with the reorganization of Spanish-era institutions today known as the National Museum, National Archives, and National Library, ${ }^{6}$ the Americans instituted a slew of legislation on the erection, protection, and conservation of various buildings, monuments, and sites reflecting Filipino national identity, though not without American interests in mind. To affirm their position as the new colonial power, by 1901 the American insular government passed Act No. 243, which declared land in Luneta as site for the construction of a monument of Dr. Jose Rizal, a leader of the propaganda movement who was murdered by the Spaniards and declared by the Americans a national hero, in the midst of the Philippine-American War merely three years after Spain ceded the Philippines to the US in the Treaty of Paris. This was followed by the 1908 Act No. 1856, to construct a pantheon of illustrious Filipinos; the 1918 Public Act No. 2760, to build, maintain, and improve national monuments, as well as to construct a monument to the revolutionary leader Andres Bonifacio; and the 1933 Executive Order (EO) No. 451, to create the Historical Research and Markers Committee (HRMC), ${ }^{7}$ responsible for marking historical antiquities in Manila and the rest of the country.

With the establishment of the Commonwealth, which was considered a transitional government for the eventual formation of the Philippines as an independent nation, two more pieces of legislation on buildings, monuments, and sites as material heritage were passed: the 1936 Commonwealth Act No. 171 , to conserve and restore Spanish colonial architecture in the District of Intramuros and replicate its style in the construction of new buildings, and the 1936 Commonwealth Act No. 169, to appropriate funds under the president's direction for the identification, preservation, and acquisition of 
historic antiquities in the country. In a message stressing the importance of the latter Act, which was modeled after the U.S. American Antiquities Act of 1906, Commonwealth President Manuel Quezon (1936) stated:

In our onward march to our national emancipation, we should not fail to look back to our past as a people so that we may be guided by its tested experience. It is, therefore, our duty not only to teach our children, and to point to the present as well as to the future generations, the heroic achievements of our forebears, the adventures they had lived as well as the mistakes they had committed, and the ideals for which they had cheerfully sacrificed their lives, but it is likewise our duty to preserve, to repair, to conserve and appropriately mark our historic antiquities and spot that abound in our country from Batanes to Mindanao. These historic antiquities are the sacred heritage of our ancestral traditions which so enhance the supreme worth of our people [emphasis added]. . . . the present and future generations may be impressed with the significance and value of those historic spots and antiquities, and that they may not be lost to posterity here and throughout the world. (para. 2-3)

Significantly, Quezon echoed Western discourse on monument and site conservation and preservation of the time in a speech that marked one of the earliest known instances in which the concept of Filipino cultural heritage had been referred to as manageable objects, buildings, monuments, or sites warranting preservation. In line with Smith's AHD, Quezon (1936) presented the "teaching" of all future generations of the greatness and "heroism" of the country's forefathers through monuments and sites, as necessary means to legitimize the nation. Noting that material heritage "enhances the supreme worth" of the Filipino, Quezon viewed heritage as crucial for establishing national identity - the fulfillment of the Commonwealth's duty to prepare for independence from the US. The barrage of building-, monument-, and site-focused legislation in order to construct a material heritage even at the inception of the American regime demonstrated how Western heritage concepts, primarily revealed through the transformation of public space, were imposed on the Philippines as institutionalized colonial policy.

Up until the postwar years, the protection of heritage remained within national boundaries as the duty of the individual state. Heritage studies scholar Rodney Harrison (2015) named three particular events that shifted the perspective toward an international, global collaboration on safeguarding and managing cultural heritage: after WWII, UNESCO's adoption of the 
1954 Convention for the Protection of Cultural Property in the Event of Armed Conflict, which equated the targeting of cultural properties during conflict to the killing of civilians; the unprecedented international assistance given to the Egyptian government to relocate ancient Egyptian temples under the threat of flooding, even as the heritage rescue project led to the displacement of 100,000 people; and international alarm over the flooding of Venice shortly after the creation of The Venice Charter, which outlined conservation practices for buildings, monuments, and sites (pp. 300-301).

The rhetoric of the "tragic loss of heritage" in the 1954 UNESCO Convention as well as the Egyptian and Venetian campaigns compelled the international community to take action, all the while solidifying and universalizing the narrative that "global cultural heritage" was constantly under threat. In turn in 1972, UNESCO adopted the groundbreaking Convention Concerning the Protection of the World Cultural and Natural Heritage (or the World Heritage Convention), which created the World Heritage List. This list contained nominated properties to protect for all humanity, according to a newly formalized, universal value system based on history, art, or science, and resulted in a global hierarchy of values (Harrison, 2015). The 1972 World Heritage Convention “institutionalized the nineteenth-century conservation ethic and the 'conserve as found' ethos" at the same time that heritage became "universally significant" (Smith, 2006, p. 27). Afterwards, international collaboration on heritage management, conservation, and preservation became a formalized priority for UNESCO member states.

\section{Cinema as Heritage and Cultural Policies under Marcos}

In UNESCO's shift to a global outlook following the 1972 Convention, "the notion of culture as political power took on added momentum by being attached to the idea of endogenous development" (UNESCO, 2004b, p. 4), entangling claims to identity with struggles for the distribution of resources in the international realm (Smith, 2012). Thus, the development of cultural heritage in service of projecting national identity became an accepted factor in legitimizing the nation on the global stage, which included institution building of national-level cultural entities among young nation states, in line with UNESCO's evolving views on heritage. While the 1972 Convention broadened parameters on what constitutes heritage from earlier definitions, its provisions did not initially encompass audiovisual materials. Frick (2011) noted that in the years leading up to the convention, the International Federation of Film Archives (FIAF), founded in 1938 by European and American institutions primarily motivated to elevate the status of films from entertainment to art, became a frequent collaborator of 
the organization. Although considered the respective national film archives within their own countries, FIAF's founding members "only envisaged the history of the art of cinema in its universal dimension, and therefore it never crossed their minds to limit their film acquisitions to their national cinemas" (Dupin, 2013, para. 3). This reflected an internationalist outlook even before UNESCO adopted the concept in its framework. Interested in cinemas beyond their borders, FIAF became involved in "rallying archival interest" among nonmember states "due to the active film and television production in those areas and the corresponding lack of national repository" (Frick, 2011, p. 109). And their efforts to establish national repositories in collaboration with UNESCO would lead to the first national film archive in the Philippines, demonstrating how the globally accepted need to develop national culture in the postwar era, most especially among UNESCO member states, coalesced with the rise of audiovisual materials as part of a global cultural heritage.

In the Philippines, the path toward the widespread recognition of audiovisual materials as cultural heritage and the establishment of national repositories proved more contentious than the construction of monuments and other national identity markers under the banner of heritage. By midcentury, cinema was widely perceived as a disposable commercial product, and while some major studios like LVN Pictures and Sampaguita Pictures began archiving their own films, others destroyed their films for silver reclamation or simply neglected them once their market value diminished (Domingo 1998; Diego 2010). ${ }^{8}$ Early Filipino pioneers in audiovisual preservation challenged the "entertainment only" perception of cinema much like their European and American counterparts, receiving dual support from UNESCO and from what journalist and author Primitivo Mijares called the "conjugal dictatorship" of Ferdinand and Imelda Marcos. The Marcoses pursued aggressive cultural policies in a bid not only to raise the international cultural heritage status of the Philippines but also in an attempt to intertwine national identity and heritage with that of their own.

After Quezon during the Commonwealth era, Ferdinand Marcos was the next president who made extensive, long-lasting changes in cultural laws and institutions, which were influenced by the First Lady and later their daughter Imee. Notably, he was the first president to employ the term "heritage" in laws he approved as well as in his executive directives. ${ }^{9}$ EO No. 30, issued in 1966, created the Cultural Center of the Philippines (CCP), one of Imelda's infamous pet projects. As per the order, one of CCP's five purposes and mandates is " $[\mathrm{t}] \mathrm{o}$ awaken the consciousness of our people to our cultural heritage, and to encourage them to assist in its preservation, promotion, enhancement and development" (Marcos, 1966). As CCP was 
mandated to handle music, performance art, and visual art, Pres. Marcos extended the definition of cultural heritage by law to encompass not only historical sites, buildings, and monuments but also diverse artistic fields and practices. In a speech delivered at the CCP in June 1970 for the Republic Cultural Heritage Awards Program, Marcos used the notion of heritage to justify and declare the need for cultural development through art:

In order to come into our own, so to speak, we must now begin, more energetically than ever before, to deepen our culture, and take the best from our cultural heritage.

Celebrating all things Filipino, in art, in music, in the dance, and in literature is only the beginning. We must also document our times, not only in the rigid framework of history, but against the larger horizons of the arts.

I do not think that our final goal as a people and as a nation is to become an economically prosperous nation. I do not think we even desire to be a so-called world power, with military might to prove it. I do not think that we aspire alone to full stomachs, or a munificent industrial complex, or a well manicured suburbia. If I may say so, what we envision is a viable nation of freemen; yes, free, and that is important because it is only in that milieu that we can enrich the spirit, through unrestricted cultural development.

... [W]e must do our best as well to nourish the Filipino spirit, to reveal its hidden beauty, to make it speak of its bright visions, and to build a precious legacy for other generations of Filipinos.

Only when we have succeeded in nourishing well our spirit can we consider ourselves as a people fully realized. (Marcos, 1970, para. 15-19)

For Marcos, cultural development through the arts expanded the definition of cultural heritage. He believed a broadened notion of heritage beyond the "rigid framework of history" advanced a pathway toward true national freedom-one that was spiritual rather than material. Even hunger was permissible as long as cultural heritage through art was used to strengthen a national Filipino identity toward the people's actualization and enlightenment. The elitist, lofty, and nationalistic ideals of the dictator provided the core philosophy behind his regime's self-serving and often contradictory cultural projects, ultimately at the expense of the Filipino 
people. Thus, Marcos's vision of heritage as the pathway to a spiritual realization of the national demonstrates that AHD is not adverse oppressive governments, as it rhetorically posits heritage and national greatness as a noble pursuit for the benefit of posterity while weaponizing it for political purposes.

Marcos' declaration of martial law over the entire Philippines on September 21, 1972, through the signing of Proclamation No. 1081, transformed the country's social, political, and economic fabric in profound ways, no less in media production and state-sanctioned cultural development. As Deocampo (1994) described it,

[A]ll forms of communication were suppressed and put
under military control. All forms of dissent were strictly
curtailed . . . By taking control of the media-cinema,
television, radio, and print-the dictatorship could
conveniently produce propaganda materials to enhance its
image among the people. . . Produced were films hailing
the 'New Society', the dictator's ideological whims, the First
Lady Imelda Marcos' globe-trotting tours, and the fascist
strength of the military. (para. 15)

The aggressive measures in cultural policy that Marcos made early into his presidency returned as a juggernaut under martial law as his regime's pursuit of cultural heritage development trudged forward, though not always in a singular direction. "National freedom" by way of cultivating cultural heritage would be achieved through selective and strategic statesanctioned support for the arts, particularly film and architecture.

Wielding culture, cinema, and heritage as tools of soft diplomacy and institutional nation building, the Marcoses appropriated UNESCO's historical approach to conflict prevention in order to mask their abuses and elevate their image domestically and abroad. With the assistance of UNESCO, the regime initiated various audiovisual archiving projects to achieve their inflated goal of national freedom via cultural expression and heritage making to attain the spiritual enlightenment of the Filipino people. UNESCO and the Marcoses' joint efforts culminated in the establishment of the country's first-ever national-level audiovisual archive, the Film Archives of the Philippines (FAP), inside the walls of the so-called "film palace" known as the Manila Film Center. They supported the efforts of pioneering audiovisual archivists Benedicto Pinga and Ernie de Pedro, who offered diverse definitions of what constituted the national and audiovisual heritage, and worked toward cultural institution building as a means to realize the national. 


\section{UNESCO and Marcosian Institution Building: The Film Archive of the Philippines}

Benedicto Pinga, ${ }^{10}$ president and founder of the Film Institute of the Philippines (FIP), which was formerly known as the Film Society of the Philippines (FSP), ${ }^{11}$ referred to a UNESCO conference excerpt in an undated report stating that "any country without at least one well-equipped archive is culturally underdeveloped" (Film Institute, n.d., p. 5). While the report did not clarify the UNESCO Conference being referred to, the mention of heritage as well as the necessity of a national film archive to indicate a nation's cultural development made clear the international organization's influence in the Philippines. According to the report, FIP aimed to revitalize the National Festival of Short Film in Manila, which had earlier editions in 1962 and 1964, believing that the project "could provide the stimulus for the preservation of Filipino documentaries as part of our cultural heritage and history" (p. 4). Pinga's report is a rare instance in which film is discussed specifically as cultural heritage prior to the existence of film archives outside of major studios and pointedly perceives documentary film as a significant part of such heritage.

Although the National Festival of Short Film was abruptly discontinued due to lack of funding, Pinga persisted in his advocacy to archive short films and documentaries by seeking to create a catalog of them (Specialized Cinema Producers of the Philippines, 1973). A 1967 article by Alejandro Roces in The Manila Chronicle referred to FIP's intent to publish a catalogue of 500 short films on "Philippine subjects" through the Board of Travel and Tourist Industry. Cataloguing efforts continued for nearly a decade according to the 1973 meeting minutes of the short film producers network, the Specialized Cinema Producers of the Philippines (CINEPRO), which was founded by Pinga and whose cataloging project was managed by Ernie de Pedro (Specialized Cinema Producers of the Philippines, 1973). By 1976 Pinga joined the Bureau of Foreign and National Information (BNFI) as a consultant to oversee "the systematic cataloging of all Filipino specialized films" ("Filipino films listed," 1976). The following year, Pinga helped BNFI organize two conferences with the UNESCO National Commission of the Philippines: "Cataloguing and Preservation of Filipino Films" and the "First Convention on Film Preservation," the latter gathering an array of government agencies, including the Marcos-run National Media Production Center, Association of Special Libraries of the Philippines, Philippine Universities Audio-Visual Center, Office for Civil Relations of the Armed Forces of the Philippines, Scientific Film Association of the Philippines, National Historical Commission, Bureau of Tourist Promotion, and Philippine Motion Picture Producers Association, and Board of Censors for Motion 
Pictures (Department of Public Information, 1977). This first collaboration with UNESCO in the field of audiovisual archiving across a multitude of sectors-film, tourism, military, academe-marked such joint projects as a priority for the Marcos regime and demonstrated its determination to institutionalize audiovisual heritage, eventually culminating in the establishment of the country's first national film archive.

By 1980 the General Conference of UNESCO in Belgrade, Yugoslavia, produced the Recommendation for the Safeguarding and Preservation of Moving Image, recognizing moving images as "an expression of the cultural identity of peoples, and because of their educational, cultural, artistic, scientific and historical value, form an integral part of a nation's cultural heritage" (UNESCO, 2004a, p. 156) while emphasizing that moving images "should be preserved in officially recognized film and television archives and processed according to the highest archival standards," with priority on "any part or all of their country's national production” (p. 158). Ernie de Pedro, short film producer, amateur film collector, and historian, who acted as the cataloging head of Pinga's CINEPRO, attended the General Conference in Belgrade after participating in the UNESCO's First Convention on Film Preservation in Manila. His selection to lead the Philippine delegation came by referral due to his interest in archiving, according to his oral account at the Philippine Cinema Heritage Summit in 2013 (National Film Archives, 2013). In Belgrade, he joined the deliberations leading to UNESCO's historic 1980 Recommendation, which widely defined moving image heritage to encompass various types of national productions in a multitude of formats as well as foreign productions that a country would consider as significant to its national identity (UNESCO 2004a). ${ }^{12}$ The Recommendation ensured that "the position of film as international heritage was ingrained, formally sanctioned, and accepted" (Frick, 2011, p. 111), providing an authorized foundation on which the audiovisual preservation movements around the globe was anchored.

Upon De Pedro's return to Manila from the UNESCO Conference, Imelda's staff asked him to act as a consultant for a possible film archive, which officials at UNESCO Paris advised her to establish (National Film Archives, 2013). While the film industry resisted the idea of a national film archive due to sheer distrust of the government regarding the requirement for producers to deposit copies of their films, De Pedro noted that Pres. Marcos' creation of a new agency-the Experimental Cinema of the Philippines (ECP)—changed their minds (National Film Archives, 2013).

In January 1981, Pres. Marcos officially lifted martial law, though the gesture was superficial as martial law policies remained in place and he still held extralegal powers (Totanes, 1998, p. 241). He prioritized and 
strengthened the state's involvement in the cultural sector, particularly in cinema, by issuing EO 640-A, which described the motion picture industry as "a truly dynamic and vigorous instrument for national cultural growth and development and vital social institution which will enhance the artistic as well as scientific heritage of the nation" (Marcos, 1981, section 1). The EO provided the guidelines for the promotion and enhancement of the preservation, growth, and development of the film industry, as well as amended the mandates of CCP to include the establishment of the Film Academy of the Philippines, Film Fund, Board of Standards, Manila Film Center, and Film Archive of the Philippines (FAP) — all of which would be under the helm of his wife. Amidst the mushrooming of new film-related institutions within CCP, he also created an independent one through EO 770: the ECP, a government-owned and controlled corporation tasked to produce and exhibit films and hold film festivals free from censorship. Film scholar Joel David (2010) noted that while the Marcoses were met with retaliation for their regime's plethora of unforgivable abuses, "in answer mainly to foreign criticisms of martial rule's repressive policies, Philippine cinema would act as their showcase of cultural democracy" (p. 232). National film production and exhibition became points through which the Marcos regime feigned images of cultural and national development and progress for the consumption of the international community.

Upon the appointment of Imee Marcos as ECP's head, it became apparent that the mandates of the new agency overlapped with that of CCP's, particularly in the management and use of the Manila Film Center. For example, the Film Center served as venue for events, exhibitions, and film festivals of both CCP and ECP, and FAP, while formally under CCP, stored the productions of ECP in its film vaults at the Film Center. ECP, though more welcomed by film industry players and considered more dynamic in operation due to Imee's stable leadership and its focus on film production and exhibition, was nonetheless mired with complex institutional politics on multiple levels due to the daughter's desire to distance herself from "the vulgarities and excesses of her mother" (David, 2016, para. 12). Mother and daughter managed their projects separately. As David noted, the "MIFF [Manila International Film Festival] ... was Imelda's territory, as [was] the Film Archives of the Philippines (FAP)" (p. 235). Under the helm of Imelda, FAP and archiving initiatives diminished in the shadow of the MIFF. The country's first international festival garnered strong international appeal and attention given its infamously luxurious and Hollywood-star-studded opening coinciding with the inauguration of the Film Center, despite an earthquake and a construction accident that led to the death of over one hundred of laborers. ${ }^{13}$ Within CCP and ECP's intertwined mandates 
championing the development of cinematic heritage as a duty of the state, national film production and exhibition took precedent over audiovisual archiving and preservation.

At the overshadowed FAP, Imelda appointed De Pedro as its inaugural director-general, upon UNESCO's recommendation (National Film Archives, 2013). A historian by training, he took interest in short turn-ofthe-century films about the Philippines prior to his stint as FAP's directorgeneral and even purchased collections of such works as a collector prior to his appointment (National Film Archives, 2013). Under his directorship he emphasized the value of such short historical films, as FAP collected works "not only those acclaimed for their artistic achievement but also those which serve as a chronicle of changing values and aspirations" (Rodriquez, 1982, p. 11), "dating back to the introduction of cinema and television in the Philippines" (Nicolas, Jr., 1982, p. 16). Under his directorship, FAP focused its archival efforts on at-risk short historical works, especially those made at the advent of cinema, including works produced by the Philippines' colonizers when the limits of the medium were continually transforming and the films produced offered complex notions of the national in the transition between the Spanish to American colonial regimes. De Pedro, like Pinga, aligned "specialized cinema," that is, short films, historical films, and documentaries, with audiovisual heritage.

In a show of support for the construction of FAP within the Manila Film Center, UNESCO dispatched as technical consultant Christopher Roads of the International Council for Film and Television Audiovisual Communication (ICFT), the organization's advisory body on audiovisual media. In his report on the project, he proclaimed that "of the hundreds of Philippine films made before 1951 not one has survived in the country" (Roads, 1981, p. 2), and this dire situation represented "few more striking, if tragic, testimonies for the need for archival facilities could be imagined" (p. 2). He revealed that UNESCO intended to use the Film Center as a model to develop film archives in the global south:

The Manila National Film Centre [sic] could serve as a possible pilot archive where new techniques for the longterm preservation of moving image media particularly suited to the needs and circumstances of the developing world can be evolved ... it is to be hoped that [it] will make a significant international contribution to the ability of future generations, perhaps thousands of years from now, to see and appreciate the twentieth century's remarkable heritage of moving images. (p. 7) 
In UNESCO's view, FAP and the Film Center made significant steps forward for the development not only of Filipino cultural heritage but also of all humanity and the reaches of posterity, reflecting the globalized turn of heritage management and preservation. After three years, thanks to the technical expertise of Roads and the dedication of De Pedro, FAP was on the verge of receiving formal recognition from FIAF as a national film archive (Domingo, 1998, p. SE-4), which would have been a first for Southeast Asia. However, despite the lofty ambitions of the Marcoses and support from UNESCO in establishing an institutionalized audiovisual archive, FAP met an early demise after just four years of operation-and with it, Pinga and De Pedro's support for the inclusion of diverse short, historical, and documentary works as audiovisual heritage-due to the Marcos ouster in 1986 after the People Power Revolt.

David (2016) noted that the ECP closed in 1985 because of the "technicality" of Imee's resignation-she wanted to focus on her legislative responsibilities, so most of the functions of ECP were transferred to the CCP and the newly established Film Development Foundation of the Philippines, the precursor of the FDCP, which focused on promotions and incentives for the film industry's growth. As for the film archive, De Pedro, like Pinga, out of his own efforts, found ways to continue audiovisual archiving projects by creatively funding FAP for another three years until 1989 (National Film Archives, 2013). However, FAP's sporadic funding did not last and the Movie and Television Review and Classification Board (MTRCB), a censorship body created in the twilight years of the Marcos regime, officially absorbed the government's film archiving responsibilities, following a provision created prior to FAP's closure that required the master negatives of all rated films be deposited to the review board. As MTRCB lacked proper archival facilities, many of FAP's audiovisual holdings were scattered among various government institutions, handed back to private collectors, or left in the basement of the abandoned Film Center. Debates went on for nearly a decade on "whether the MTRCB is the proper place for an archives division" (Miranda, 1997, p. 23) due to the concern that a censorship body's primary duty is to alter films for commercial exhibition, not to archive or preserve them.

While MTRCB's archiving division eventually closed, the transfer of audiovisual archival duties to the censorship body solidified years of constructing audiovisual heritage around feature-length narrative cinema. This marked a notable departure from Pinga and De Pedro's investment in short, historical, and documentary works, which were soon marginalized in the dominating discourses surrounding audiovisual heritage following the end of FAP. FAP's unceremonious termination exposed the extent to which 
audiovisual archiving was devalued within the chaotic structure of CCP and $\mathrm{ECP}$, whose institutional prioritization consistently eclipsed the functions of the FAP. While CCP and ECP's film production, exhibition, and film festival programs at the Manila Film Center were retained and undertaken by government bodies mandated by law to carry out such cultural work, the national film archive did not have the same trajectory. The ensuing destabilization and eventual decentralization of archival institutions paved the way for shortsighted curatorial and archival practice based on a naturalized audiovisual heritage hierarchy that privileges an industrial view of cinema.

\section{Naturalizing the Industrial View of Audiovisual Heritage}

Over the next two-and-a-half decades, the closure of the state-initiated FAP led to an "era of cooperation and collaboration in a decentralized archival advocacy among the largest remaining audiovisual archives in the country" (Lim, 2013, p. 16), including the participation of the following institutions: CCP, Philippine Information Agency (PIA), University of the Philippines Film Institute (UPFI), Mowelfund Film Institute (MFI), LVN Pictures, Sampaguita Pictures, and ABS-CBN Corporation, with the National Commission on Culture and the Arts (NCCA) providing occasional support for film restoration projects. Many audiovisual archives within the network, particularly government, academic, and independent members, faced the same perennial problems that FAP never managed to overcome: lack of funding and facilities, deprioritization as sub-departments of parent agencies, and institutional instability. Largely ignored by the state, the network's members, namely UPFI and MFI led by PIA and CCP, had to seek international support through the Association of Southeast Asian Nations (ASEAN).

The sense of ASEAN regional audiovisual archiving was born together with a need to formalize the nodal audiovisual network in the Philippines, following the 1993 Conference and Workshop on ASEAN Audio/Video Film Retrieval, Restoration, and Archiving in Manila. The archival network officially registered as a non-profit and non-governmental organization called the Society of Filipino Archivists for Film (SOFIA) the same year and played a central role in the founding and launching of the South East AsiaPacific Audiovisual Archive Association (SEAPAVAA) by 1996, with the Philippines taking the lead in audiovisual archiving in the ASEAN region. SOFIA's momentum soon transformed into a campaign and decisive actions toward the reestablishment of a national film archive. SOFIA worked closely with the National Film and Sound Archive in Australia (NFSA), a fellow SEAPAVAA member and an institution closely involved with UNESCO, in 
planning the Philippines' national film archive in 1996. However, changing political tides at the national level-that is, the ouster of former President Joseph Ejercito Estrada-eventually ended support for the project in 2001, similar to how Marcos' ouster led to the downfall of FAP.

The sudden and lackadaisical disposal of films by LVN Pictures, a major studio and driving force of the film industry during the so-called "golden age" of Philippine cinema in the postwar era, spurred SOFIA into action in 1994, solidifying the hierarchal organization of audiovisual heritage postFAP by continuing to prioritize feature-length narrative cinema. Professor Clodualdo del Mundo, Jr. (2004), former SOFIA president, recounted how the organization's founding members had rushed to an outdoor basketball court where LVN dumped thousands of film cans: "Passionate archivists hoped that they could find little treasures in the mountain of films ... and listed 24 titles as top priority for rescue" (p. 16). The incident spurred SOFIA to pen a document titled "Draft Elements for a Master Plan to Save the Philippines' Film Heritage," which cited that the organization "was called upon by the film industry to draft a master plan for the development of film" (Mendoza, 1994, p. 1). By 1997, PIA and SOFIA presented to NCCA a project proposal that listed 19 films for restoration and cleaning, and proclaimed the titles to be of "high heritage value" based on the following criteria: "endangered Filipino film classics whose survival is in immediate risk unless promptly restored; films that are sociologically, culturally, historically and artistically significant; landmark films or sample films of a specific genre" (as cited in Lim, 2013, p. 19). The list, ${ }^{14}$ primarily consisting of feature films directed by National Artists and those produced by major studios, reflected the AHD value system in which the heritage curation process embraced an industrial view of cinema, perceiving it to best service national identity formation out of all other forms of moving image practice.

Although SOFIA members inspected and inventoried their highly diverse collections comprising of short films and videos, experimental and student films, documentaries, historical footage, and other orphaned works, feature-length narrative film restoration became the centerpiece of their archival practice in their attempts to achieve a broad base of support to reestablishing a national film archive. This demonstrated how the necessity of national-level institution building remained the marker of national cultural development. Likewise, emphasis on restoring and exhibiting feature-length narrative cinema became a convenient way to attract a wider audience for their advocacies, especially from the film industry itself. Their efforts to professionalize audiovisual archiving through SEAPAVAA workshops and international training seminars, while constructive on the small scale, did little to address deep-seated archival infrastructure and funding problems. 
For SOFIA, film restoration and exhibition were deemed as more realistic goals, considering that long-term preservation, much less any other forms of access, was impossible in resource-strapped and deprioritized archival entities. The hegemony of restoring feature-length narrative cinema in archival practice reflects SOFIA's adoption and naturalization of a hierarchy that privileges an industrial view of the medium.

UNESCO's heritage-as-national ethos as well as the repercussions from Marcos-era state-sanctioned cultural policies provided the outline for SOFIA's audiovisual archiving script, which they inherited and chose to follow in their curatorial and archival practices. This script has always been premised on the inherent need to protect and preserve audiovisual heritage toward national identity formation, enlist a circle of experts to define and defend a heritage canon that fits the state's prevailing definitions of the national, and return to national-level institution building by calling for the reestablishment a national film archive. Advocating for the featurelength narrative film as the highest expression of audiovisual heritage and restoration as prioritized archival practice, SOFIA solidified a specific film canon of primarily industry-produced titles as representative of audiovisual heritage, thus setting the precedent that would be followed by FDCP and $\mathrm{ABS}-\mathrm{CBN}$ years later after the two institutions acquired many of the collections formerly held by SOFIA members. The script determined that cinematic fictions in the linear, feature-length, narrative form hold the highest position in the audiovisual heritage hierarchy, given such fictions' power to engender national self-consciousness through storytelling, providing "templates through which history can be written and national identity figured" (Shohat \& Stam, 2014, p. 102); that the institutionalized national film archive project feature-length narrative films "as national accomplishments, as conveyors of cultural identity" (De Vlack, 2007, p. 24); and that any other goal beyond contributing and servicing the authorized national narrative remain peripheral.

The NCCA attempted to address problems faced in national cultural heritage preservation through the National Cultural Heritage Act of 2009, which was the culmination of decades of heritage management laws modeled after UNESCO's conventions that supported the monolithic use of cultural heritage "in pursuit of cultural preservation as a strategy for maintaining Filipino identity" ("National Cultural Heritage Act," 2009, para. 2) and protections for declared cultural properties. However, a perceivable gap remains in the attention given to audiovisual heritage. Sections 31 and 32 of the Act outline the designated national cultural agencies and institutional linkages tasked with the designation, categorization, and assessment of national cultural properties and treasures. Of the eighteen government 
bodies listed, ${ }^{15}$ none of them hold the specific responsibility of assessing audiovisual materials as cultural property or national cultural treasures, thus excluding said materials formal recognition, protection, and privileges under the law. Clauses that contain catch-all phrases in Section 5, such as the declaration that "works by national artists" or "all archival materials or documents older than fifty years" (National Cultural Heritage Act, 2009, para. 7) are automatically considered important cultural properties, are ineffective, given audiovisual materials' sheer lack of representation under the designated government bodies. Such conditions deter possibilities to create more inclusive definitions of audiovisual heritage, and points to the continued dominance of the industrial view of audiovisual heritage in the foreseeable future and the ironic failure of institutionalized AHD in the Philippines to fulfill baseline preservation objectives.

\section{Conclusion}

Cultural heritage as expressed in policies during the American colonial regime up to the Marcos dictatorship fostered the naturalization of Western models of AHD as proof of national cultural development by defining heritage as a manageable and tangible set of objects with fixed meanings; privileging grand expressions of national identity; guarding a closed circle of heritage gatekeepers; and claiming the necessity of nationallevel cultural institutions, however bereft of effective archival practice. All of these models continue to persist today. Smith (2012) warned that AHD is far from passive, wielding authority to "regulat[e] and govern the political and cultural meaning of the past" (para. 7) so that "the assumed meaning in inherent heritage, and the past and culture it represents, will not be changed or challenged" (para. 16). She noted that AHD suppresses subnational or community-determined views of heritage that resist and question authorized ones, fails to acknowledge AHD embedded in public policy since heritage "just is," and ensures that dominant institutions' values and knowledge are universalized and formalized by certified experts. In the Philippines, decades of prioritizing and institutionalizing an authorized curation of what constitutes the national within audiovisual heritage have limited and constrained potentialities in the meaning and uses of such heritage.

To break free of such constricting authority, archivist Verne Harris (2001) advocated that those in the profession must become aware of their position and resist power-even their own-from within the institution by "listen[ing] intently for the voices of those who are marginalised or excluded by prevailing relations of power" (p. 11). Examining the history of constructing Filipino heritage and its influences on audiovisual archiving 
and preservation presents an opportunity to reassess the archival mission itself, such that it may be challenged and transformed. Archival practices must translate into critical engagement well beyond the institution, with the goals of renegotiating, disrupting, and diminishing boundaries of authority, all the while cultivating community-initiated and independent audiovisual archiving initiatives, transparent accessibility of the archival entities, and diverse participation of those who define what constitutes audiovisual heritage. 


\section{References}

Cook, T., \& Schwartz, J. M. (2002). Archive, records, and power: From (postmodern) theory to (archival) performance. Archival Science, 2, 171-185.

Cruz, M. R. (2016, April 14). Over 100 Filipino classic films restored. Philippine Daily Inquirer. Retrieved from http://entertainment.inquirer.net/193492/over-100-filipino-classic-films-restored.

Cruzado, J. A. (2012). The storage and preservation of Philippine films in the ABS-CBN Film Archives and the MOWELFUND Audiovisual Archive (Unpublished undergraduate thesis). University of the Philippines, Quezon City, Philippines.

David, J. (2010). Awake in the dark: Philippine film during the Marcos era. In P. Patajo-Legasto (Ed.), Philippine studies: Have we gone beyond St. Louis? (pp. 227-243). Quezon City: University of the Philippines Press.

David, J. (2016, March 25). Grains \& flickers. Ámauteurish! Retrieved from https://amauteurish. com/2016/03/25/grains-flickers/.

Del Mundo, C., Jr. (2004). Dreaming of a national audio-visual archives: Two essays. Manila: Society of Film Archivists.

Deocampo, N. (1994). From revolution to revolution. Yamagata international documentary film festival. Retrieved from https://www.yidff.jp/docbox/5/box5-3-e.html.

Deocampo, N. (2011). Film: American influences on Philippine cinema. Manila: Anvil.

Department of Budget and Management. (2016). National expenditure program 2016: Film Development Council of the Philippines. Republic of the Philippines: Department of Budget and Management. Retrieved from http://www.dbm.gov.ph/wpcontent/uploads/ NEP2016/OEO/H.pdf.

Department of Public Information Philippines. (1977, December 12). First convention on film preservation programme. Manila: Author.

Domingo, G. A. (1998, November 28). The need to preserve and restore our cinematic gems. The Philippine Star, p. SE-4.

Dupin, C. (2013). The origins of FIAF, 1936-1938. International Federation of Film Archives. Retrieved from http://www.fiafnet.org/pages/History/Origins-of-FIAF.html

Filipino films listed. (1976, May 3). Times Journal.

Film Development Council of the Philippines. (2014). National Film Archives of the Philippines annual report. Manila: Author.

Film Institute of the Philippines. (n.d.). Brief study on the National Festival of Filipino Documentaries. Manila: Author.

Frick, C. (2011). Saving cinema:The politics of preservation. Oxford: Oxford University Press.

Harris, V. (2001). Seeing (in) blindness: South Africa, archives and passion for justice [PDF document]. Retrieved from http://scnc.ukzn.ac.za/doc/LibArchMus/Arch/Harris_V_Freedom_of_information_ in_SA_Archives_for_justice.pdf.

Harrison, R. (2015). Heritage and globalization. In E. Waterton \& S. Watson (Eds.), The Palgrave handbook of contemporary heritage research (pp. 297-312). London: Palgrave Macmillan.

Hobsbawm, E. (1983). Mass-producing traditions: Europe, 1870-1914. In E. Hobsbawm \& T. Ranger (Eds.), The invention of tradition (pp. 263-307). Cambridge: Cambridge University Press. 
Lim, B.C. (2013). A brief history of archival advocacy for Philippine cinema.2013 Philippine cinema heritage summit: A report. Manila: Film Development Council of the Philippines.

Marcos, F.E.(1966, June 25). Executive order No.30, s. 1966. Official Gazette of the Republic of the Philippines. Retrieved from http://www.officialgazette.gov.ph/1966/06/25/ executive-order-no-30-s-1966/.

Marcos, F.E. (1970,June 12). Address of president Marcos at the republic cultural heritage awards program. Official Gazette of the Republic of the Philippines. Retrieved from http://www.officialgazette.gov. ph/1970/06/12/address-of-president-marcos-at-the-republic-cultural-heritage-awards-program/.

Marcos, F. E. (1981, January 5). Executive order No. 640-A, s. 1981. Official Gazette of the Republic of the Philippines. Retrieved from http://www.officialgazette.gov.ph/ 1981/01/05/executive-order-no640-a-s-1981/.

Mendoza, A. (1994). Draft elements for a master plan to save the Philippines' film heritage. Manila: Society of Film Archivists.

Miranda, O. (1997, October 19). Film archives of the Philippines now a reality, again. Sunday Chronicle, p. 23.

National Cultural Heritage Act, R. A. 10066, 14th Cong. (2009) (enacted). The LAWPHiL Project. Retrieved from http://www.lawphil.net/statutes/repacts/ra2010/ra_10066_2010.html.

National Film Archives of the Philippines. (2013).2013 Philippine cinema heritage summit:A report. Manila: Film Development Council of the Philippines.

Nicolas, N., Jr. (1982, September 27). There's an urgent need to preserve Filipino films. Times Journal, pp. $16,19$.

Quezon, M. L. (1936, October 27). Message of president Quezon to the first national assembly on appropriation of P50,000 for identifying and marking historic antiquities in the Philippines, October 27, 1936. Official Gazette of the Republic of the Philippines. Retrieved from http://www. officialgazette.gov.ph/1936/10/27/message-of-president-quezon-to-the-first-national-assemblyon-appropriation-of-p50000-for-identifying-and-marking-historic-antiquities-in-the-philippinesoctober-27-1936/.

Rafael, V. L. (2000). White love and other events in Filipino history. Durham, NC: Duke University Press.

Roads, C. (1981). The Manila National Film Centre [PDF document]. Retrieved from http://unesdoc.unesco. org/images/0004/000472/047235eo.pdf.

Roces, A. R. (1967, February 1). National Museum should have a film library. The Manila Chronicle.

Rodriguez, M. C. (1982, January 28). Archives up at film center. Bulletin Today, p. 11.

Samonte, M. G. (1986, September). Underground movies. Movement Magazine, 1(4). 20-21.

San Diego, B., Jr. (2010, September 13). Inside the Kapamilya film vaults. Philippine Daily Inquirer. Retrieved from https://www.pressreader.com/philippines/philippine-daily-inquirer/20100913/28715721950 7304.

Shohat, E., \& Stam R. (2014). Unthinking Eurocentrism: Multiculturalism and the media (2nd ed.). New York, NY: Routledge.

Smith, L. (2006). Uses of heritage. Abingdon: Routledge, Taylor and Francis Group.

Smith, L. (2012). Discourses of heritage: Implications for archaeological community practice. Nuevo Mundo Mundos Nuevos. DOI : 10.4000/nuevomundo.64148.

Society of Filipino Archivists for Film. (1997). Consultation meeting establishing the national film/video archive facility. Manila: Author. 
Society of Filipino Archivists for Film. (2014). Advocates for film preservation: Organizational profile. ISSUU. Retrieved from https://issuu.com/ramonchito/docs/sofia_-_org_profile_2013.

Society of Filipino Archivists for Film and National Commission for Culture and the Arts. (2005). Philippine audiovisual archives collections: An inventory. Manila: Author.

Specialized Cinema Producers of the Philippines. (1973, August 15). Minutes of the meeting of the Specialized Cinema Producers of the Philippines. Manila: Author.

Stubbs, J.H., \& Makaš, E. G. (2011).Architectural conservation in Europe and the Americas. Hoboken, NJ: John Wiley \& Sons.

Totanes, H. S. (1998). Kasaysayan (the story of the Filipino people): A timeline of Philippine history (Vol. 10). Hong Kong: Asia Publishing Company Limited.

UNESCO. (2004a). Records of the general conference twenty-first session Belgrade, 23 September to 28 October 1980 [PDF document]. Retrieved from http://unesdoc.unesco.org/images/0011/001140/114029e. pdf\#page $=153$.

UNESCO. (2004b). UNESCO and the issue of cultural diversity: Review and strategy, 1946-2004 [PDF document]. Retrieved from http://www.unesco.org/culture/culturaldiversity/ docs_pre_2007/ unesco_diversity_review_strategy_1946_2004_en.pdf.

\section{Notes}

1 See footnote 13.

2 FDCP's digital restoration projects include (in order of completion) Genghis Khan (1965), Maynila sa Mga Kuko ng Liwanag (1975), Insiang (1976), A Portrait of the Artist as Filipino (1965), Pagdating sa Dulo (1971), and most recently, Zamboanga (1936).

3 For statistics on the holdings of FDCP see Film Development Council of the Philippines (2014). For a summary of its collections, see footnote 14. For budget allocation to film preservation see Department of Budget and Management (2016).

4 As noted by Lim (2013), the turnover of collections of smaller institutions is due to the fact that FDCP and ABS-CBN Film Archives are the only audiovisual archives in the country with (a) open acquisition policies and (b) 24/7 climate-controlled vaults. In sum, FDCP adopted audiovisual collections from different government agencies through Administrative Order No. 26, including those from the Philippine Information Agency, University of the Philippines Film Center Film Archive, Historical Commission of the Philippines, Movie Television Review and Classification Board, and Intramuros Administration. Through voluntary deposit, it also contains collections from independent and private entities like the Mowelfund Audiovisual Archive, Goethe Institute Manila, Sampaguita Pictures, Premiere Productions, Unico Pictures, Mandarin Laboratory, SQ Film Laboratory, and individual filmmakers and producers. ABS-CBN Film Archives holds all Star Cinema productions as well as feature-length film titles acquired for restoration and rerelease. These include titles produced by a myriad of production companies as well as those sourced from different public and private entities such as the Cultural Center of the Philippines. For details on FDCP and ABS-CBN's collections and acquisition policies, see Film Development Council of the Philippines (2014) and Cruzado (2012). Beyond FDCP and ABS-CBN, private and independent entities such as Regal Films and FPJ Film Archives maintain their own archives.

5 Smith (2006) noted that the 2003 Convention for the Safeguarding of the Intangible Cultural Heritage emerged only when non-Western nations criticized the 1972 World Heritage Convention's 
exclusion of such heritage (p.28).

6 The Spanish regime initially established the National Museum, National Library, and National Archives, the first two by Royal Order No. 689 in 1887 and was then called the Royal Museo-Biblioteca de Filipinas. The last one existed as the Spanish Division of Archives since at least the 1700s. During the American Commonwealth era, the Institute of National Language was established in 1936 by former president Manual Quezon through Act No. 184. While under the Americans, the transformation of public space remained the central mode of instilling a sense of heritage through materials means. The National Museum, National Library, and National Archives went through numerous stages of reorganization under the Americans, less prioritized for projecting Filipino national identity but more entangled with formalizing American bureaucratic administrative functions. These early cultural institutions were modeled on well-established Western norms of authorized expressions of national identity.

7 The HMRC is the precursor to today's National Historical Commission of the Philippines.

8 On the remaining domestically-produced films since 1897, the Society of Filipino Archivists for Film (SOFIA) noted that the early producers' destruction and neglect of these films are the cause of their low survival rate (Domingo, 1998; Diego, 2010).

9 Following Pres. Quezon's use of the term "heritage," his successors also used the term in their speeches and written messages, though not in laws or executive directives they signed.

10 Refer to Deocampo (2011) and Lim (2013) for biographies of Benedicto Pinga.

11 FSP was considered "the first underground film group in the country" (Samonte, 1986, p. 20) whose members produced some of the earliest experimental Filipino films, reflecting Pinga's preoccupation with what he calls "specialized films" beyond the standard narravive feature-length commercial fare.

12 The Recommendation broadly defines three categories of moving images:"(i) cinematographic productions (such as feature films, short films, popular science films, newsreels and documentaries, animated and educational films); (ii) television productions made by or for broadcasting organizations; (iii) videographic productions (contained in videograms) other than those referred to under (i) and (ii) above" (UNESCO 2004a). Furthermore, it defines moving image heritage as follows:"All moving images of national production should be considered by Member States as an integral part of their'moving image heritage.' Moving images of original foreign production may also form part of the cultural heritage of a country when they are of particular national importance from the point of view of the culture or history of the country concerned" (UNESCO 2004a).

13 The first Manila International Film Festival opening and the simultaneous inauguration of the Manila Film Center pushed through despite an accident during construction that trapped numerous laborers in cement. As the former first lady allegedly made the decision to bury the laborers on site in order to meet the construction deadline, the Marcoses justified developing cultural heritage in exchange for human life, not unlike the earlier UNESCO project that led to the displacement of 100,000 people for the sake of saving ancient Egyptian temples. Refer to David (2016) for details on MIFF's controversies.

14 See Del Mundo (2004), Lim (2013), and Society of Filipino Archivists (2014) for the full list of films.

15 Led by the NCCA, these include the Cultural Center of the Philippines, National Archives of the Philippines, National Library, National Historical Institute (now the National Historical Commission), National Museum, Komisyon sa Wikang Filipino, Department of Tourism, Intramuros Administration, 
Department of Education, Department of Public Works and Highways, National Commission on Indigenous Peoples, Department of Environment and Natural Resources, Department of the Interior and Local Government, Office on Muslum Affairs, UNESCO National Commission of the Philippines, Housing and Land Use Regulatory Board, Autonomous Region in Museum Mindanao and the Cordillera Administrative Region, and the Office of the Special Envoy on Transnational Crimes ("National Cultural Heritage Act," 2009). While the National Archives of the Philippines is responsible for overseeing significant archival materials, it lacks the facilities to maintain its own collections of audiovisual materials and has not engaged in official coordination with any of the audiovisual archiving institutions in the country regarding the assessment of audiovisual materials as cultural property and/or treasure in line with the 2009 Act.

BERNADETTE ROSE ALBA PATINO served as an audiovisual archivist at the Philippine Film Archives (formerly the National Film Archives of the Philippines), under the auspices of the Film Development Council of the Philippines, after receiving her degree in Slavic Languages and Literatures from Indiana University. In fall 2018, she will begin pursuing her MS in Library and Information Science at the Pratt Institute School of Information in New York City. (corresponding author: bpatino@pratt.edu) 
